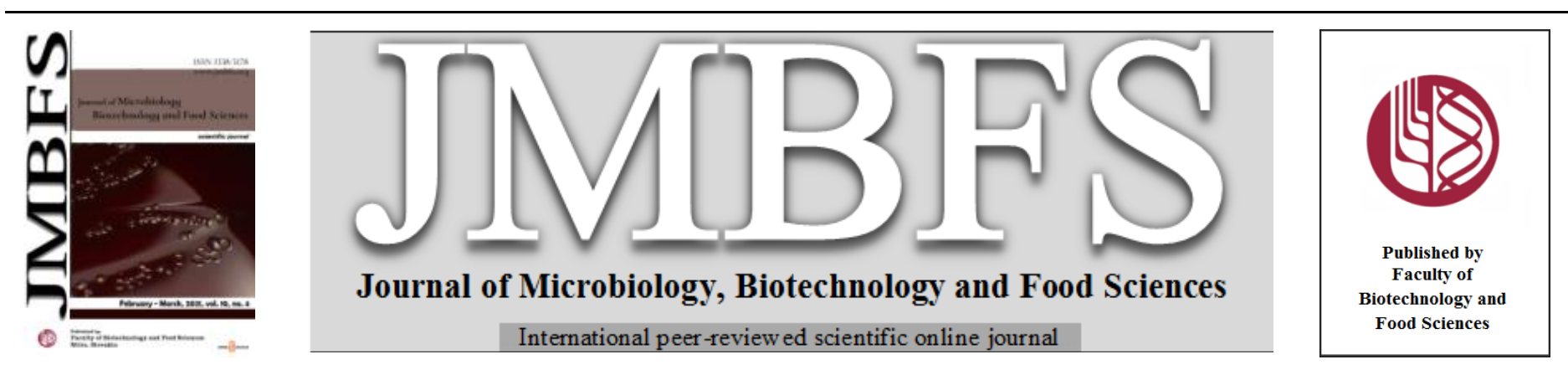

\title{
UTILIZATION OF MICROWAVE ASSISTED EXTRACTS OBTAINED FROM VARIOUS PARTS (WHOLE FRUIT, SEEDS, LEAVES AND ROOTS) OF CITRULLUS COLOCYNTHIS AS HYPOCHOLESTEROLEMIC AGENT IN ALBINO RATS
}

\author{
Anees Ahmed Khalil ${ }^{1}$, QuratulAin Shahid**1, Ayesha Aslam ${ }^{1}$, Ahood Khalid ${ }^{1}$, Miroslava Hlebová ${ }^{2}$, Maksim Rebezov $^{3,4,5}$, Georgy \\ Peshcherov ${ }^{6}$, Eleonora Okuskhanova ${ }^{7}$, Mohammad Ali Shariati $^{* 7}$
}

\author{
Address(es): \\ ${ }^{1}$ University of Lahore, Faculty of Allied Health Sciences, University Institute of Diet and Nutritional Sciences, 1-km Defense road, near Bhuptian chowk, Lahore, \\ Punjab, Phone no. (042)111-865-865. \\ ${ }^{2}$ University of SS. Cyril and Methodius, Department of Biology, Faculty of Natural Sciences, Nám. J. Herdu 2, SK-91701 Trnava, Slovak Republic. \\ ${ }^{3}$ V. M. Gorbatov Federal Research Center for Food Systems of Russian Academy of Sciences, Moscow, Russian Federation. \\ ${ }^{4}$ Prokhorov General Physics Institute, Russian Academy of Sciences, Moscow, Russian Federation. \\ ${ }^{5}$ Russian state agrarian correspondence university, Balashikha, Russian Federation. \\ ${ }^{6}$ Research Institute of the Federal Penitentiary Service of Russia. \\ ${ }^{7}$ Shakarim State University of Semey, Semey, Kazakhstan.
}

*Corresponding author: quratulain351@gmail.com, m.ali.sh@semgu.kz

doi: 10.15414/jmbfs.2021.10.4.541-545

\section{ARTICLE INFO}

Received 9. 6. 2020

Revised 23. 9. 2020

Accepted 24. 9. 2020

Published 1.2. 2021

Regular article

open $\partial_{\text {Access }}$

\begin{abstract}
The study was conducted to investigate the hypolipidemic properties of Microwave assisted extracts (MAE) obtained from different parts (whole fruit, leaves, seeds and roots) of Citrullus colocynthis on hyperlipidemic experimental rats. The trial consisted of 30 male rats that were divided into six groups each having 5 rats whereas, out of these 25 were hyperlipidemic and 5 were normal rats. After the induction of high cholesterol for 15 days, 20 rats were fed with microwave assisted extract of different parts at a concentration of $200 \mathrm{mg} / \mathrm{kg} / \mathrm{B}$. W for 28 days. The administration of the extracts reported considerable reduction in the lipid profile parameters of the hypercholesterolemic rats. The MAE of seed of Citrullus colocynthis displayed the optimum results showing reduced levels of cholesterol, triglyceride and LDL-c by (10.33\%), (22.50\%) and (15.70\%) while an elevation of (16.75\%) in HDL-c content compared to the hypercholesterolemic control. Likewise, the percent increase in the concentrations of CAT and SOD by (6.92\%) and (18.47\%). The study concluded that the MAE of Citrullus colocynthis showed a positive effect on hypercholesterolemia thus providing therapeutic benefits.
\end{abstract}

Keywords: Citrullus colocynthis, Hyperlipidemia, Microwave Assisted Extracts, Cholesterol

\section{INTRODUCTION}

Medicinal plants have been known through centuries, due to its potential properties against different diseases and infections. Most of the time such plants are gigantic source of Antioxidants, Flavonoids, Phenolic compounds and Phytochemicals (Demmig-Adams and Adams, 2002). These plants having medicinal properties have vital role throughout world in treating different ailments. As the synthetic medicines have been known to cause many side effects and less effective upon diseases, so the approach to cure diseases with natural medications has increased tremendously (Nimruzi et al., 2013).

Citrullus colocynthis has been used as source of energy and remedy for many diseases since early times.it is commonly known as Colocynth, Bitter cucumber, Bitter melon. It is generally grown in desert regions of Asia and Mediterranean regions. Citrullus colocynthis looks like a vine having hard rind small fruits and leaves on it. Roots of the plant have been used to treat snake poison, urinanry tract infection, jaundice, pains in bones and diseases related to eyes. Leaves of Citrullus colocynthis were helpful in therapy for asthma, diuretics and jaundice. Fruit and seeds of Citrullus colocynthis has anti diuretics, anthelmintic effect (Shahid et al., 2019). It also cures tumor, urinary tract infection, joints inflammation, ulcers and asthma diseases. Extracts obtained from different parts of this plant such as stem, leaves, roots, seeds or fruit have positive effect on different ailments (Qureshi et al.,2010).

The extraction of components from different plants has been done by numerous techniques. Conventional and non-conventional techniques are practiced since centuries. Non-conventional methods have many benefits such as environmentally friendly, as it consumes less chemicals, less operational time and yields excellent quality of extract as compared to conventional methods (Uma and Sekar, 2014). Microwave assisted extraction (MAE) is one of the unique methods for extracting materials form plants by the help of microwave rays/energy. Microwave assisted extraction technique as numerous advantages such as increased extraction of components from plants due to quick heating, increase extraction yield and small equipment utilized. Due to immense qualities it has been used to extract organic and organo-metallic components from various plants (Alupului et al., 2012). By considering advantages of MAE, this study was conducted to work on extracts obtained from different parts (whole fruit, leaves, seeds and roots) of Citrullus colocynthis by microwave assisted extraction.

\section{MATERIAL AND METHOD}

\section{Plant Material}

Various parts of Citrullus colocynthis i.e. roots, leaves, seed, \& whole fruit was procured from local market of Lahore. These parts were washed, and air-dried at room temperature. Collected roots, leaves, seeds and whole fruit was dried in oven drier at $50 \pm 5^{\circ} \mathrm{C}$ to minimize the moisture content. After that they were grinded to reduce the particle size in order to facilitate extraction.

\section{Preparation of Extract}

Extraction of Bitter melon roots, leaves, seeds \& whole fruit was carried in an adapted commercial kitchen microwave oven. The maximum output of this oven was $700 \mathrm{~W}$. In the MAE procedure, a $25 \mathrm{~g}$ aliquot of Bitter melon roots, leaves, seeds \& whole fruit powder was individually placed in a $250 \mathrm{ml}$ round bottom flask; $25 \mathrm{ml}$ of distilled water was added to moisturize for $30 \mathrm{~min}$. The flask was connected to a Clevenger apparatus and heated at powers of $150 \mathrm{~W}$ for varied 
extraction time 1, 5, 10 and 15 minutes respectively. The volatile distillate was eluted out by $\mathrm{n}$-hexane and dried through anhydrous sodium sulphate. The $\mathrm{n}$ - hexane was removed under vacuum conditions and the extract was refrigerated prior to analysis (Liu et al., 2013)

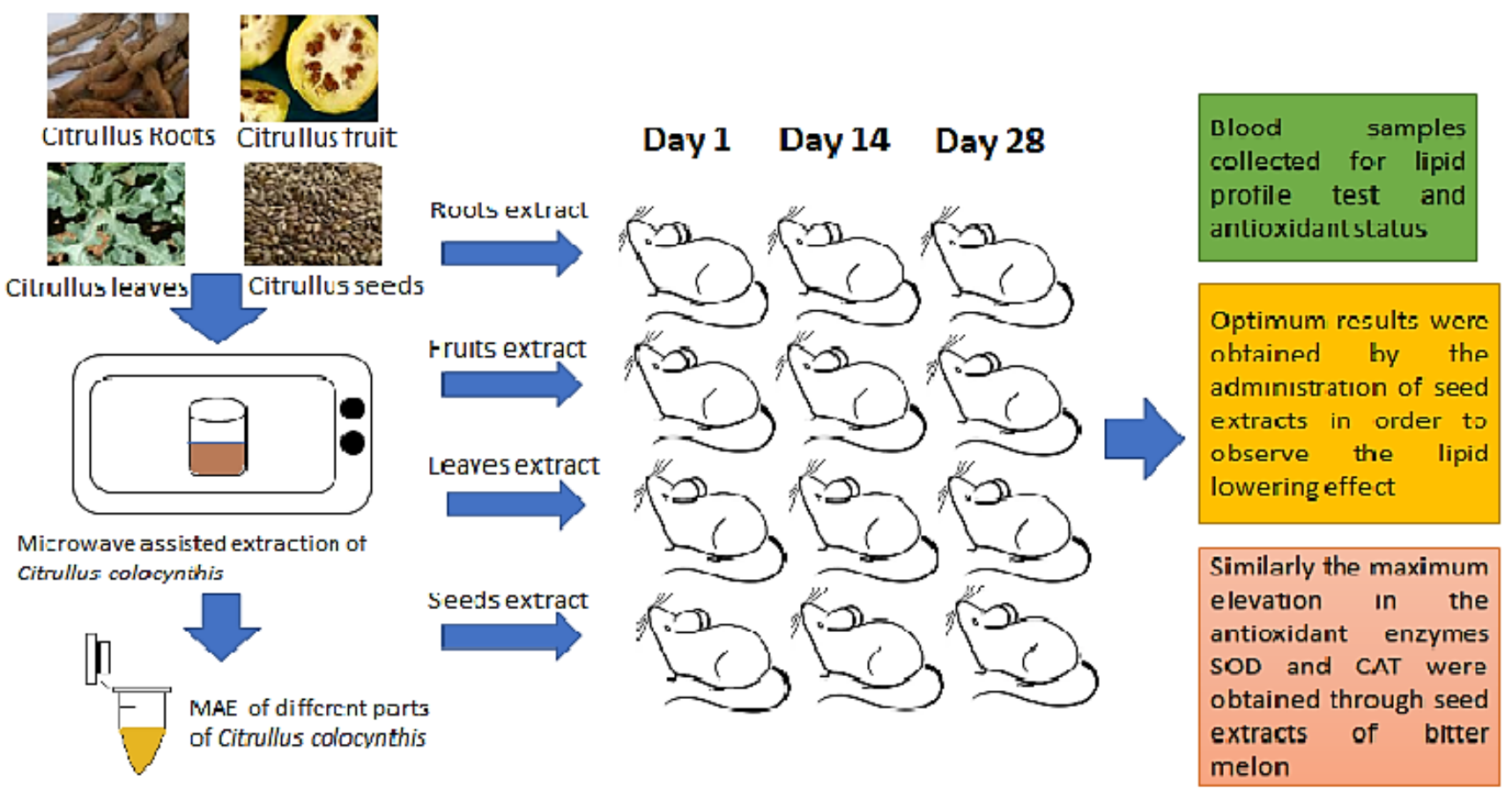

Figure 1 Graphical representation of experimental design. Microwave assisted extraction of different parts (roots, leaves, fruits and seeds) and their administration to the rats. Analysis of the blood samples after completion of study interval to verify the effect of each part in lowering of lipid

\section{Experimental Animals}

Male rats were purchased from animal house of Institute of Molecular Biology and Biotechnology (IMBB), The University of Lahore, having weight between $200 \mathrm{~g}-250 \mathrm{~g}$. The rats were kept for 1 week on basal diet for acclimatization purpose. The environmental conditions were controlled throughout the trial like temperature $\left(23 \pm 2{ }^{\circ} \mathrm{C}\right)$ and relative humidity $(55 \pm 5 \%)$ along with 12 -h lightdark period.

\section{Induction of Hypercholesterolemia}

Experimental hypercholesterolemic diet was prepared using corn oil (10\%), corn starch $(64.5 \%)$, cholesterol $(1.5 \%)$, protein $(10 \%)$, cellulose $(10 \%)$, mineral $(3 \%)$ and vitamins (1\%). Groups were subjected to high cholesterol diet for first 15 days for induction of hypercholesterolemia. This was authenticated by examining their total cholesterol content at $15^{\text {th }}$ day. Rats were anesthetized by exposure to isoflurane and the blood samples were collected through cardiac puncture (Imran et al., 2018).

\section{Experimental design}

30 rats were divided into groups, each comprising of 5 rats in them. Group $\mathrm{N}_{0}$ normal control rats fed with their normal diet, Group $\mathrm{C}_{0}$ was fed with only with high cholesterol diet. Group $\mathrm{C}_{1}$ was administered with high cholesterol diet along with Citrullus colocynthis whole fruit extract. Group $\mathrm{C}_{2}$ was administered with high cholesterol diet along with Citrullus colocynthis leaves extract. Group $\mathrm{C}_{3}$ was administered with high cholesterol diet along with Citrullus colocynthis seeds extract. Group $\mathrm{C}_{4}$ was administered with high cholesterol diet along with Citrullus colocynthis roots extract (Kai et al.,2015).

\section{Effect of extract on hyper cholesterol and safety assessment}

Rats was anesthetized by exposure to isoflurane and the blood samples was collected in tubes by cardiac puncture and examined at 0 day (baseline trend), $15^{\text {th }}$ day (post administration of cholesterol rich diet) and $21^{\text {st }}$ day post induction of hypercholesterolemia along with administration of respective extracts to validate hypocholesterolemic effect (Imran et al., 2018).

\section{Statistical analysis}

Data were expressed as mean \pm standard deviation and completely randomized design was conducted with two-way (Serum profiling \& Antioxidant indices) ANOVA at a significance level of $\mathrm{p} \leq 0.05$ (Steel et al., 1997)

\section{RESULTS}

\section{Total Cholesterol}

The statistical analysis demonstrated that there was significant $(p \leq 0.05)$ effect of treatment and time intervals on the cholesterol concentrations of the rats. The effect of MAE obtained from different parts of Citrullus colocynthis on total cholesterol are mentioned in table 1. Results for the cholesterol content displayed highest percent reduction in treatment group $\mathrm{C}_{3}(10.33 \%)$ followed by $\mathrm{C}_{1}$ $(9.84 \%), \mathrm{C}_{2}(9.26 \%)$ and $\mathrm{C}_{4}(8.20 \%)$, respectively on the $28^{\text {th }}$ day of administrating MAEs. In comparison to the control group Co (195.27 \pm 2.67 $\mathrm{mg} / \mathrm{dL})$, the cholesterol concentrations noted in treatment groups were $176.05 \pm 2.07 \mathrm{mg} / \mathrm{dL}\left(\mathrm{C}_{1}\right), 177.18 \pm 2.38 \mathrm{mg} / \mathrm{dL}\left(\mathrm{C}_{2}\right), 175.08 \pm 1.83 \mathrm{mg} / \mathrm{dL}\left(\mathrm{C}_{3}\right)$, and $179.24 \pm 2.87 \mathrm{mg} / \mathrm{dL}\left(\mathrm{C}_{4}\right)$, respectively. The cholesterol content reduced from $187.38 \pm 2.99 \mathrm{mg} / \mathrm{dL}$ ( 0 day) to $180.63 \pm 2.20 \mathrm{mg} / \mathrm{dL}\left(14^{\text {th }}\right.$ day) and $173.49 \pm 1.81$ $\mathrm{mg} / \mathrm{dL}\left(28^{\text {th }}\right.$ day), respectively. The highest reduction was observed in in group $\mathrm{C}_{3}$ as compared to $\mathrm{C}_{0}$.

\section{Total Triglycerides}

The statistical analysis demonstrated that there was significant $(p \leq 0.05)$ effect of treatment and time intervals on the triglyceride content of the hypercholesterolemic rats. The effect of microwave assisted extracts obtained from different parts of Citrullus colocynthis on total triglycerides have been displayed in figure 2. Results for total triglycerides observed in $\mathrm{C}_{\mathrm{o}}$ $(173.72 \pm 2.33 \mathrm{mg} / \mathrm{dL})$ was found to have reduced in $\mathrm{C}_{1}(137.96 \pm 3.21 \mathrm{mg} / \mathrm{dL}), \mathrm{C}_{2}$ $(139.09 \pm 2.10 \mathrm{mg} / \mathrm{dL}), \mathrm{C}_{3}(134.33 \pm 1.09 \mathrm{mg} / \mathrm{dL})$ and $\mathrm{C}_{4}(141.56 \pm 3.33 \mathrm{mg} / \mathrm{dL})$. The figure displayed a significant percent reduction in $\mathrm{C}_{3}(22.50 \%)$ as compared to experimental group followed by $\mathrm{C}_{1}(20.02 \%), \mathrm{C}_{2}(19.09 \%)$ and $\mathrm{C}_{4}(18.18 \%)$ at the $28^{\text {th }}$ day of administration of extracts. 
Table 1 Effect of MAE of different parts of Citrullus colocynthis on Total Cholesterol

\begin{tabular}{|c|c|c|c|c|c|}
\hline \multirow{2}{*}{ Parameter } & \multirow{2}{*}{ Group } & \multicolumn{4}{|c|}{ Days } \\
\hline & & 0 day & $14^{\text {th }}$ Day & 28 day & Mean \\
\hline \multirow{7}{*}{ 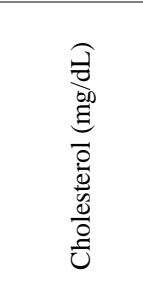 } & $\mathrm{N}_{0}$ & $94.21 \pm 0.40$ & $96.78 \pm 0.25$ & $99.35 \pm 1.76$ & $96.78 \pm 0.80$ \\
\hline & $\mathrm{C}_{0}$ & $185.34 \pm 2.23$ & $194.60 \pm 2.66$ & $205.88 \pm 3.12$ & $195.27 \pm 2.67^{\mathrm{a}}$ \\
\hline & $\mathrm{C}_{1}$ & $187.11 \pm 3.21$ & $176.44 \pm 1.41$ & $164.61 \pm 1.16$ & $176.05 \pm 2.07^{\mathrm{bc}}$ \\
\hline & $\mathrm{C}_{2}$ & $188.21 \pm 3.12$ & $177.10 \pm 2.71$ & $166.23 \pm 1.33$ & $177.18 \pm 2.38^{\mathrm{bc}}$ \\
\hline & $\mathrm{C}_{3}$ & $186.84 \pm 2.48$ & $175.25 \pm 1.52$ & $163.15 \pm 1.51$ & $175.08 \pm 1.83^{\mathrm{c}}$ \\
\hline & $\mathrm{C}_{4}$ & $189.40 \pm 3.94$ & $179.74 \pm 2.74$ & $168.59 \pm 1.95$ & $179.24 \pm 2.87^{b}$ \\
\hline & Mean & $187.38 \pm 2.99^{\mathrm{a}}$ & $180.63 \pm 2.20^{\mathrm{b}}$ & $173.49 \pm 1.81^{\mathrm{c}}$ & $180.29 \pm 2.33$ \\
\hline
\end{tabular}

$\mathrm{N}_{0}$. Normal group; $\mathrm{C}_{0}$ : Control group (HCD); $\mathrm{C}_{1}: \mathrm{HCD}+$ Microwave Assisted Citrullus colocynthis whole fruit extract; $\mathrm{C}_{2}$ : $\mathrm{HCD}+\mathrm{Microwave}$ Assisted Citrullus colocynthis leaves extract; $\mathrm{C}_{3}$ : HCD+Microwave Assisted Citrullus colocynthis seeds extract; $\mathrm{C}_{4}: \mathrm{HCD}+\mathrm{Microwave}$ Assisted Citrullus colocynthis roots extract HCD=High Cholesterol Diet

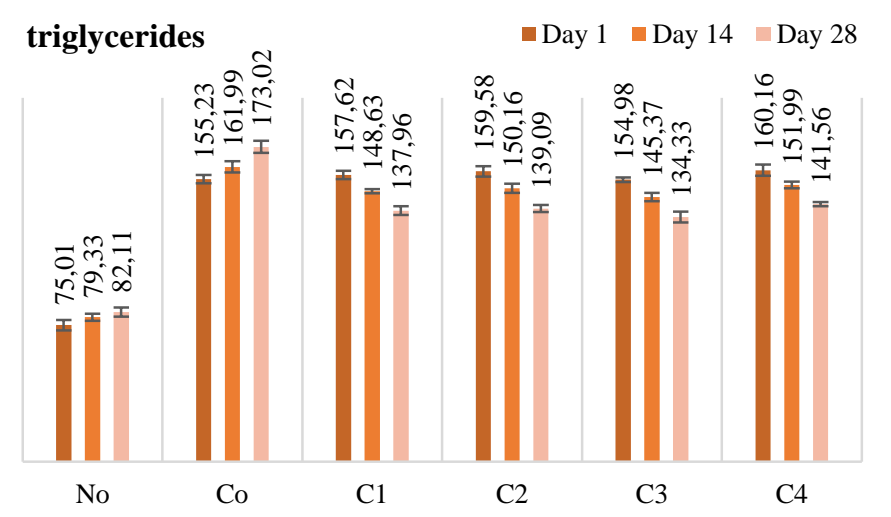

Figure 2 Effect of MAE of different parts of Citrullus colocynthis on Total Triglycerides

$\mathrm{N}_{0}$ : Normal group; $\mathrm{C}_{0}$ : Control group (HCD); $\mathrm{C}_{1}$ : $\mathrm{HCD}+$ Microwave Assisted Citrullu colocynthis whole fruit extract; $\mathrm{C}_{2}: \mathrm{HCD}+$ Microwave Assisted Citrullus colocynthis leaves extract; $\quad \mathrm{C}_{3} \mathrm{HCD}+$ Microwave Assisted Citrullus colocynthis seeds extract; $\mathrm{C}_{4}: \mathrm{HCD}+$ Microwave Assisted Citrullus colocynthis roots extract $\mathrm{HCD}=$ High Cholesterol Diet
LDL

The Statistical analysis revealed that there was significant $(p<0.05)$ effect on treatments and intervals $(0,14 \& 28$ days $)$ on LDL levels of experimental rats. The values of MAE from various parts of Citrullus colocynthis and their effect on total LDL levels have been mentioned in table 2. Results for the LDL content displayed peak reduction in treatment group $\mathrm{C}_{3}(15.70 \%)$ followed by $\mathrm{C}_{1}$ $(13.95 \%), \mathrm{C}_{2}(11.77 \%)$ and $\mathrm{C}_{4}(11.66 \%)$, respectively on the $28^{\text {th }}$ day of administrating MAE. In comparison to the control group Co $(113.76 \pm 2.01 \mathrm{mg} / \mathrm{dL})$, the highest reduction in LDL concentrations were observed in $\mathrm{C}_{3} \quad(95.27 \pm 2.48 \mathrm{mg} / \mathrm{dL})$ followed by $\mathrm{C}_{1}(97.89 \pm 1.57 \mathrm{mg} / \mathrm{dL})$, $\mathrm{C}_{2}(100.36 \pm 1.94 \mathrm{mg} / \mathrm{dL})$ and $\mathrm{C}_{4}(100.49 \pm 1.70 \mathrm{mg} / \mathrm{dL})$, respectively. Furthermore, the value for LDL level at 0 day was $106.20 \pm 1.87 \mathrm{mg} / \mathrm{dL}$ which reduced to $101.44 \pm 1.66 \mathrm{mg} / \mathrm{dL}$ at $14^{\text {th }}$ day and to $97.03 \pm 1.94 \mathrm{mg} / \mathrm{dL}$ at $28^{\text {th }}$ day, respectively.

Table 2 Effect of MAE of different parts of Citrullus colocynthis on LDL

\begin{tabular}{|c|c|c|c|c|c|}
\hline \multirow{2}{*}{ Parameter } & \multirow{2}{*}{ Group } & \multicolumn{3}{|c|}{ Days } & \multirow[b]{2}{*}{ Mean } \\
\hline & & 0 day & $14^{\text {th }}$ Day & 28 day & \\
\hline \multirow{7}{*}{$\overrightarrow{\mathrm{G}}$} & $\mathrm{N}_{0}$ & $38.44 \pm 1.22$ & $42.63 \pm 1.24$ & $45.76 \pm 1.34$ & $42.27 \pm 1.26$ \\
\hline & $\mathrm{C}_{0}$ & $108.11 \pm 2.13$ & $112.93 \pm 1.39$ & $120.25 \pm 2.52$ & $113.76 \pm 2.01^{\mathrm{a}}$ \\
\hline & $\mathrm{C}_{1}$ & $105.92 \pm 2.11$ & $97.64 \pm 1.57$ & $90.11 \pm 1.04$ & $97.89 \pm 1.57^{\mathrm{c}}$ \\
\hline & $\mathrm{C}_{2}$ & $107.56 \pm 1.75$ & $101.49 \pm 2.18$ & $92.04 \pm 1.91$ & $100.36 \pm 1.94^{\mathrm{bc}}$ \\
\hline & $\mathrm{C}_{3}$ & $102.49 \pm 1.28$ & $95.12 \pm 2.19$ & $88.22 \pm 2.27$ & $95.27 \pm 2.48^{\mathrm{d}}$ \\
\hline & $\mathrm{C}_{4}$ & $106.91 \pm 2.11$ & $100.01 \pm 1.01$ & $94.55 \pm 1.99$ & $100.49 \pm 1.70^{b}$ \\
\hline & Mean & $106.20 \pm 1.87^{\mathrm{a}}$ & $101.44 \pm 1.66^{\mathrm{b}}$ & $97.03 \pm 1.94^{\mathrm{c}}$ & \\
\hline
\end{tabular}

$\mathrm{N}_{0}$. Normal group; $\mathrm{C}_{0}$ : Control group (HCD); $\mathrm{C}_{1}: \mathrm{HCD}+$ Microwave Assisted Citrullus colocynthis whole fruit extract; $\mathrm{C}_{2}: \mathrm{HCD}+$ Microwave Assisted Citrullus colocynthis leaves extract; $\mathrm{C}_{3} \mathrm{HCD}+$ Microwave Assisted Citrullus colocynthis seeds extract; $\mathrm{C}_{4}: \mathrm{HCD}+$ Microwave Assisted Citrullus colocynthis roots extract $\mathrm{HCD}=$ High Cholesterol Diet

HDL

The Statistical analysis revealed that there was significant $(p \leq 0.05)$ effect on treatments and intervals on HDL of experimental rats. The values of MAE from various parts of Citrullus colocynthis and their effect on total HDL levels have been mentioned in table 3 Results for the HDL content displayed peak percent elevation in treatment group (16.75\%) $\mathrm{C}_{3}$ followed by $(9.74 \%) \mathrm{C}_{1},(9.64 \%) \mathrm{C}_{2}$ and $(4.50 \%) \mathrm{C}_{4}$, respectively on the $28^{\text {th }}$ day of administrating MAE. In comparison to the control group Co $(32.90 \pm 0.69 \mathrm{mg} / \mathrm{dL})$, the highest HDL concentrations observed in $\mathrm{C}_{3}(39.52 \pm 1.56 \mathrm{mg} / \mathrm{dL})$ then $\mathrm{C}_{1}(36.41 \pm 0.83 \mathrm{mg} / \mathrm{dL})$, $\mathrm{C}_{2}(36.02 \pm 0.88 \mathrm{mg} / \mathrm{dL})$ and $\mathrm{C}_{4}(34.45 \pm 0.92 \mathrm{mg} / \mathrm{dL})$. Similar, mean values of day intervals were, 0 day $(34.04 \pm 1.18 \mathrm{mg} / \mathrm{dL}) .14^{\text {th }}$ day $(36.08 \pm 1.16 \mathrm{mg} / \mathrm{dL})$ and $28^{\text {th }}$ day $(37.66 \pm 0.59 \mathrm{mg} / \mathrm{dL})$.

Table 3 Effect of MAE of different parts of Citrullus colocynthis on HDL

\begin{tabular}{|c|c|c|c|c|c|}
\hline \multirow{2}{*}{ Parameter } & \multirow{2}{*}{ Group } & \multicolumn{3}{|l|}{ Days } & \multirow{2}{*}{ Mean } \\
\hline & & 0 day & $14^{\text {th }}$ Day & 28 day & \\
\hline \multirow{7}{*}{$\overrightarrow{\hat{\theta}}$} & $\mathrm{N}_{0}$ & $39.11 \pm 1.12$ & $41.39 \pm 0.56$ & $43.98 \pm 1.21$ & $41.49 \pm 0.96$ \\
\hline & $\mathrm{C}_{0}$ & $35.03 \pm 1.23$ & $32.76 \pm 0.45$ & $30.91 \pm 0.39$ & $32.90 \pm 0.69^{\mathrm{c}}$ \\
\hline & $\mathrm{C}_{1}$ & $32.71 \pm 0.51$ & $35.26 \pm 1.85$ & $41.26 \pm 0.15$ & $36.41 \pm 0.83^{\mathrm{b}}$ \\
\hline & $\mathrm{C}_{2}$ & $33.81 \pm 0.48$ & $36.07 \pm 1.89$ & $38.19 \pm 0.28$ & $36.02 \pm 0.88^{\mathrm{b}}$ \\
\hline & $\mathrm{C}_{3}$ & $36.39 \pm 1.78$ & $39.89 \pm 1.05$ & $42.30 \pm 1.87$ & $39.52 \pm 1.56^{\mathrm{a}}$ \\
\hline & $\mathrm{C}_{4}$ & $32.29 \pm 1.91$ & $34.42 \pm 0.56$ & $36.65 \pm 0.29$ & $34.45 \pm 0.92^{\mathrm{b}}$ \\
\hline & Mean & $34.04 \pm 1.18^{c}$ & $36.08 \pm 1.16^{\mathrm{b}}$ & $37.66 \pm 0.59^{\mathrm{a}}$ & \\
\hline
\end{tabular}

$\mathrm{N}_{0}$ : Normal group; $\mathrm{C}_{0}$ : Control group (HCD); $\mathrm{C}_{1}$ : HCD+ Microwave Assisted Citrullus colocynthis whole fruit extract; $\mathrm{C}_{2}: \mathrm{HCD}+\mathrm{Microwave}$ Assisted Citrullus colocynthis leaves extract; $\mathrm{C}_{3} \cdot \mathrm{HCD}+$ Microwave Assisted Citrullus colocynthis seeds extract; $\mathrm{C}_{4}: \mathrm{HCD}+$ Microwave Assisted Citrullus colocynthis roots extract $\mathrm{HCD}=$ High Cholesterol Diet 


\section{Superoxide Dismutase (SOD)}

The statistical analysis observed significant $(\mathrm{p} \leq 0.05)$ effect of variables (time intervals and treatments) on the SOD levels in hypercholesterolemic experimental rats. The results for the effect of MAE on the levels of SOD are mentioned in table 4 . The levels of SOD were elevated from $(12.66 \pm 0.22 \mathrm{IU} / \mathrm{L})$ at
0 day, to $13.46 \pm 0.11 \mathrm{IU} / \mathrm{L}$ at $14^{\text {th }}$ day and to $14.22 \pm 0.13 \mathrm{IU} / \mathrm{L}$ at $28^{\text {th }}$ day respectively. However, the values observed for $\mathrm{C}_{0}(11.78 \pm 0.18 \mathrm{IU} / \mathrm{L})$ were noticed to have elevated in $\mathrm{C}_{1}(13.19 \pm 0.07 \mathrm{IU} / \mathrm{L}), \mathrm{C}_{2}(13.50 \pm 0.18 \mathrm{IU} / \mathrm{L}), \mathrm{C}_{3}$ $(14.45 \pm 0.30 \mathrm{IU} / \mathrm{L}), \mathrm{C}_{4}(14.30 \pm 0.03 \mathrm{IU} / \mathrm{L})$, respectively. The percentage elevation in the treatment groups showed highest increase in $\mathrm{C}_{3}(18.47 \%)$.

Table 4 Effect of MAE of different parts of Citrullus colocynthis on SOD (IU/L)

\begin{tabular}{|c|c|c|c|c|c|}
\hline \multirow{2}{*}{ Parameter } & \multirow{2}{*}{ Group } & \multicolumn{3}{|c|}{ Days } & \multirow{2}{*}{ Mean } \\
\hline & & 0 day & $14^{\text {th }}$ Day & 28 day & \\
\hline \multirow{7}{*}{ 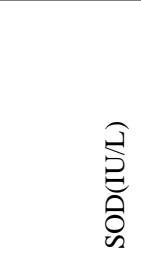 } & $\mathrm{N}_{0}$ & $13.22 \pm 0.20$ & $13.78 \pm 0.11$ & $14.01 \pm 0.22$ & $13.67 \pm 0.17$ \\
\hline & $\mathrm{C}_{0}$ & $12.62 \pm 0.25$ & $11.71 \pm 0.12$ & $11.02 \pm 0.19$ & $11.78 \pm 0.18^{\mathrm{d}}$ \\
\hline & $\mathrm{C}_{1}$ & $12.09 \pm 0.08$ & $13.24 \pm 0.04$ & $14.25 \pm 0.10$ & $13.19 \pm 0.07^{\mathrm{c}}$ \\
\hline & $\mathrm{C}_{2}$ & $12.12 \pm 0.19$ & $13.69 \pm 0.15$ & $14.71 \pm 0.22$ & $13.50 \pm 0.18^{\mathrm{b}}$ \\
\hline & $\mathrm{C}_{3}$ & $13.14 \pm 0.50$ & $14.44 \pm 0.22$ & $15.79 \pm 0.19$ & $14.45 \pm 0.30^{\mathrm{a}}$ \\
\hline & $\mathrm{C}_{4}$ & $13.34 \pm 0.02$ & $14.23 \pm 0.02$ & $15.33 \pm 0.05$ & $14.30 \pm 0.03^{\mathrm{b}}$ \\
\hline & Mean & $12.66 \pm 0.22^{\mathrm{c}}$ & $13.46 \pm 0.11^{\mathrm{b}}$ & $14.22 \pm 0.13^{\mathrm{a}}$ & \\
\hline
\end{tabular}

$\mathrm{N}_{0}$ : Normal group; $\mathrm{C}_{0}$ : Control group (HCD); $\mathrm{C}_{1}$ : $\mathrm{HCD}+$ Microwave Assisted Citrullus colocynthis whole fruit extract; $\mathrm{C}_{2}$ : HCD+Microwave Assisted Citrullus colocynthis leaves extract; $\mathrm{C}_{3}: \mathrm{HCD}+$ Microwave Assisted Citrullus colocynthis seeds extract; $\mathrm{C}_{4}: \mathrm{HCD}+$ Microwave Assisted Citrullus colocynthis roots extract $\mathrm{HCD}=$ High Cholesterol Diet

\section{Catalase}

The statistical analysis showed the effect of time interval and treatment to be significant $(p<0.05)$ on the levels of catalase in hypercholesterolemic experimental rats. The means for the values of CAT are reported in the figure 3 The levels of catalase observed in $\mathrm{C}_{0}(14.79+0.13 \mathrm{IU} / \mathrm{L})$ was shown to have elevated in $\mathrm{C}_{1}(14.11 \pm 0.21 \mathrm{IU} / \mathrm{L}), \mathrm{C}_{2}(15.56 \pm 0.13 \mathrm{IU} / \mathrm{L}), \mathrm{C}_{3}(15.89 \pm 0.24 \mathrm{IU} / \mathrm{L})$ and $\mathrm{C}_{4}(14.44 \pm 0.03 \mathrm{IU} / \mathrm{L})$, respectively on the $28^{\text {th }}$ day of administration. The percent elevation observed in experimental groups were $4.60 \%, 4.94 \%, 6.92 \%, 2.36 \%$, respectively.

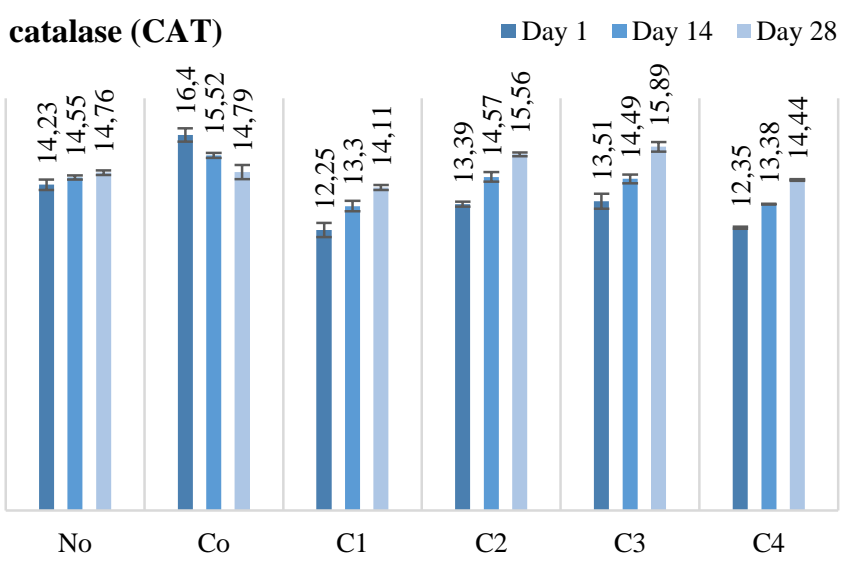

Figure 3 Effect of MAE of different parts of Citrullus colocynthis on Catalase (IU/L)

$\mathrm{N}_{0}$ : Normal group; $\mathrm{C}_{0}$ : Control group (HCD); $\mathrm{C}_{1}$ : Microwave Assisted Citrullus colocynthis whole fruit extract; $\mathrm{C}_{2}$ : Microwave Assisted Citrullus colocynthis leaves extract; $\mathrm{C}_{3}$ : Microwave Assisted Citrullus colocynthis seeds extract; $\mathrm{C}_{4}$ : Microwave Assisted Citrullus colocynthis roots extract

HCD=High Cholesterol Diet

\section{DISCUSSION}

Citrullus colocynthis has been known as traditional medicine since ages, due to presence of major nutrients and flavonoids. It has been used in many countries to treat ailments, specially diabetes mellitus (Errajraji et al., 2010). Our findings are not in harmony to the findings of Adam et al, because the dosage prescribed was $0.25 \mathrm{~g} / \mathrm{kg}$, which was orally administered to sheep for less than two weeks (Adam et al., 2001). Studies have shown that fruit and leaves of Citrullus colocynthis have many constituents such as cucurbitacin (A, B, C and D) (Nayab et al., 2006). According to Khouri et al. (2007) reduction was seen in cholesterol and triglycerides in hyperlipidemic patients that were fed on $500 \mathrm{mg} / \mathrm{kg} / \mathrm{BW}$ of powdered seeds of Citrullus colocynthis. The antihyperlipidimic influence of Citrullus colocynthis fruit is accredited due to occurrence of bioactive components i.e. isoflavoninis, two cucurbitan triterpene glycosides, colocynthosides A and B (Yoshikawa et al., 2007). According to Zamani et al., extract obtained from seeds and fruit of Citrullus colocynthis has significantly reduced LDL and triglycerides and HDL levels were increased (Subhan $\boldsymbol{e t}$ al., 2008). The reduction in cholesterol is basically because of high amount of saponins in different parts of Citrullus colocynthis, that combines with cholesterol and excretes out of body (Ren et al., 2001). According to Agarwal et al., reported that aqueous extract of roots has significantly reduced the serum blood profile as compared to extracts obtained from other solvents (benzene, chloroform and ethyl alcohol) (Agarwal et al., 2012).

Different parts of Citrullus colocynthis are enriched with flavonoids and phenolic compounds due to which ii possess antioxidantative properties. The studies have shown that fruit and fruit pulp extracts have effect on enzymes (catalase and SOD) that protects from oxidative damage (Dallak et al., 2010). According to studies, reduction in these enzymes in body is due to less synthesis of enzymes due to high accumulation of radicals (Xiong et al., 2015). According to Nessa and Khan methanolic extract of Citrullus colocynthis leaves have the highes phenolic content so it inhibits the highest effect on oxidative enzyme, as compared to extract obtained from cholorform (Nessa and Khan, 2014). Simila roots extract of Citrullus colocynthis have positive effect on enzymes and protects the body from going under stress condition (Agarwal et al., 2012).

\section{CONCLUSION}

The study concluded that different parts of Citrullus colocynthis possess lipid lowering properties. In addition to this, MAE extracts can be used to treat the disease related to altered lipid profile. Further experiments are also required to investigate the therapeutic influence to validate its curative use.

Acknowledments: The authors would like to acknowledge University Institute of Diet and Nutritional Sciences, The University of Lahore for their cooperation.

\section{REFERENCES}

Adam, S. E. I., Al-Yahya, M. A., \& Al-Farhan, A. H. (2001). Response of Najdi sheep to oral administration of Citrullus colocynthis fruits, Nerium oleander leaves or their mixture. Small Ruminant Research, 40(3), 239244. https://doi.org/10.1016/s0921-4488(01)00184-5.

Alupului, A., Calinescu, I., \& Lavric, V. (2012). Microwave extraction of active principles from medicinal plants. UPB Science Bulletin, Series B, 74(2), 129-142. Demmig-Adams, B., \& Adams, W. W. (2002). Antioxidants in photosynthesis and human nutrition. Science, 298(5601), 2149-2153 https://doi.org/10.1126/science.1078002

Errajraji, A., Ouhdouch, F., \& El-Anssari, N. (2010). Use of medicinal plants for type 2 diabetes treatment, in Morocco. Medicine of Metabolic Diseases, 4 (3), 301-304.

Kai, N. S., Nee, T. A., Ling, E. L. C., Ping, T. C., Kamariah, L., \& Lin, N. K. (2015). Anti-hypercholesterolemic effect of kenaf (Hibiscus cannabinus L.) seed on high-fat diet Sprague dawley rats. Asian Pacific journal of tropical medicine, 8(1), 6-13. https://doi.org/10.1016/s1995-7645(14)60179-6.

Khouri, N. A., El-Akawi, Z., \& Daradka, H. (2007). Effect of Short-Term Treatment with Citrullus colocynthis L on the Lipid Profile and Other Blood Biochemical Parameters in Albino Rats. Asian Journal of Chemistry, 19(2), 1468 Nayab, D., Ali, D., Arshad, N., Malik, A., Choudhary, M. I., \& Ahmed, Z (2006). Cucurbitacin glucosides from Citrullus colocynthis. Natural Product Research, 20(5), 409-413. https://doi.org/10.1080/14786410500044997.

Nessa, F., \& Khan, S. A. (2014). Evaluation of antioxidant and xanthine oxidase inhibitory activity of different solvent extracts of leaves of Citrullus colocynthis Pharmacognosy Research, 6(3), 218. https://doi.org/10.4103/0974-8490.132599. Nimruzi, M., Salehi, A. R., \& Imanieh, M. H. (2013). Impotence and Iranian traditional medicine. Journal of Islamic and Iranian traditional medicine, 3(4), 435-442.

Qureshi, R., Bhatti, G. R., \& Memon, R. A. (2010). Ethnomedicinal uses of herbs from northern part of Nara desert, Pakistan Journal of Botany, 42(2), 839-851. 
Ren, M. Q., Kuhn, G., Wegner, J., \& Chen, J. (2001). Isoflavones, substances with multi-biological and clinical properties. European Journal of Nutrition, 40(4), 135-146. https://doi.org/10.1007/p100007388.

Shahid, Q., Khalil, A. A., Faiz-ul-Hassan, S., Khan, A. A., Hina, G., Khan, M. A., ... \& Sameen, A. (2019). Proximate and mineral nutrient composition of various parts of Citrullus colocynthis-an underutilized plant. Pakistan Journal of Food Sciences, 29(2), 10-14.

Subhan, N., Alam, M. A., Ahmed, F., Shahid, I. J., Nahar, L., \& Sarker, S. D. (2008). Bioactivity of Excoecaria agallocha. Revista Brasileira de Farmacognosia, 18(4), 521-526. https://doi.org/10.1590/s0102$695 \times 2008000400004$.

Uma, C., \& Sekar, K. G. (2014). Phytochemical analysis of a folklore medicinal plant Citrullus colocynthis L (bitter apple). Journal of Pharmacognosy and Phytochemistry, 2(6).

Xiong, Z. E., Dong, W. G., Wang, B. Y., Tong, Q. Y., \& Li, Z. Y. (2015). Curcumin attenuates chronic ethanol-induced liver injury by inhibition of oxidative stress via mitogen-activated protein kinase/nuclear factor E2-related factor 2 pathway in mice. Pharmacognosy Magazine, 11(44), 707. https://doi.org/10.4103/0973-1296.165556.

Yoshikawa, M., Morikawa, T., Kobayashi, H., Nakamura, A., Matsuhira, K. Nakamura, S., \& Matsuda, H. (2007). Bioactive saponins and glycosides. XXVII. Structures of new cucurbitane-type triterpene glycosides and antiallergic constituents from Citrullus colocynthis. Chemical and pharmaceutical bulletin, 55(3), 428-434. https://doi.o.rg/10.1248/cpb.55.428 